\title{
Sodomitical Butterflies: Male Homosexual Desire in Colonial
} Latin America

\author{
Joseph Wawzonek
}

When the Spanish arrived in the New World and wrote of their conquests, gruesome imagery was shared in a concentrated effort to vilify the indigenous populations. Three aspects of these cultures particularly grabbed the minds of Europeans: cannibalism, sacrificial rituals, and sodomy. To the European population, this trifecta of savagery represented the extent of the devil's corruption of these cultures. Sodomy especially stood out as many, if not all, indigenous Latin American societies had a role for same-sex eroticism. The Maya had a religious role for sodomy, as seen in the Books of Chilam Balam, ${ }^{1}$ the Inka tinku brought opposite gendered individuals closer, ${ }^{2}$ and Mexica boys would frequently penetrate one another in temples and schools. Spanish ideology and theology viewed same-sex relations as an affront against God, the sin which must not be named, and a flame which must be stamped out. This paper will demonstrate the roles of male homosexuality prior to and during Spanish imperialism, how sodomy was perceived throughout the history of Latin America, the culture of honour in regards to homosexuality, and the consequences of male same-sex desire in Spain's American colonies.

Prior to the arrival of the Spanish, ideas such as homosexuality ${ }^{3}$ and transgender identity ${ }^{4}$ were not understood by the indigenous peoples of the Americas as they are

\footnotetext{
${ }^{1}$ See Pete Sigal, "Gendered Power, the Hybrid Self, and Homosexual Desire in Late Colonial Yucatan," in Infamous Desire, ed. Pete Sigal (Chicago: University of Chicago Press, 2003), 111-112.

${ }^{2}$ See Michael J. Horswell, "Toward an Andean Theory of Ritual Same-Sex Sexuality and Third-Gender Subjectivity," in Infamous Desire, ed. Pete Sigal (Chicago: University of Chicago Press, 2003), 30-33.

${ }^{3}$ It is difficult to apply a completely accurate term to describe same-sex sexuality in early Latin America, homosexuality will thus be used to describe a large set of behaviours, desires, and discourses associated with same-sex activity. See Pete Sigal, "(Homo)Sexual Desire and Masculine Power in Colonial Latin America: Notes Toward an Integrated Analysis," ed. Pete Sigal (Chicago: University of Chicago Press, 2003),4-8.

${ }^{4}$ Non-binary gender identity as it is known today in the western world was and was not present. Some individuals (namely the berdache) did partake in transvesting themselves and were seen as a 'third gender,'
} 
presently. Though same-sex attraction and mismatching between gender identity and assigned sex were present, the aspect of sin did not enter the equation of a non-binary individual's worth. It is certainly true that many Nahua and Maya peoples detested those participating in sodomy - especially the passive partner - in non-religious circumstances. This is seen in the Florentine Codex, wherein the Nahua condemned the passive penetrated partner, claiming such an individual "fills people's noses with the smell of excrement. Effeminate. He passes himself off as a woman. He deserves to be cast in the fire." 5 The active partner, however, did not receive such inflammatory remarks, as nobles and shamans in Maya society were said to sodomitically rape the gods to display power. If the penis of the penetrating male was not humiliating enough for a deity, a shaman could supposedly use the genitalia of the god's parents to rape the penis and anus at once incestuously. ${ }^{6}$ These groups thusly did not outright despise sodomy - they saw sacred roles for such acts - rather, they preferred masculine, active sexual roles to feminine, passive roles. ${ }^{7}$

This love-hate relationship with homosexuality was not as pronounced among Andean societies like the Inka and Moche. Among the Moche the feminine has been revealed to be increasingly important in sacrificial ceremonies, and also represents the role of homosexuality in ritual contexts. ${ }^{8}$ Erotic ceramics produced by these peoples have especially illustrated the extent of same-sex activity, with male skeletons penetrating living individuals dressed in masculine attire, and pairs of masculine skeletons kissing and

but it is difficult to say if these individuals actually identified with the gender identity placed upon them, especially as many berdaches were forced into this gendered role from early childhood. See Horswell, "Toward an Andean Theory;" Richard C. Trexler, "Gender Subordination and Political Hierarchy in PreHispanic America," ed. Pete Sigal (Chicago: University of Chicago Press, 2003).

${ }^{5}$ Sigal, "Gendered Power," 104. The Florentine Codex was compiled by a Franciscan friar using Nahua informants. The intention was to be ethnographically accurate. Other documentation also reveals perceived weakness and femininity in the passive partner.

${ }^{6}$ Sigal, "Gendered Power," 111-113. It is not entirely clear if this act does indeed count as incest in the Maya perspective. Though the genitalia of the god's parents are used to commit a sexual act, the parents themselves were not active participants. The genitalia were 'free-floating' and attached to the body of the noble or shaman acting out the rape. Regardless, this act legitimised the nobility and furthered the shaman's power over the sacred.

${ }^{7}$ See Trexler, "Gender Subordination," 73. The ruler of one political unit in the Valley of Mexico is written as having focused the ambassador of another leader to dress as a woman for the duration of his journey back to Tenochtitlan.

${ }^{8}$ Horswell, "Toward an Andean Theory," 33. 
embracing one another. ${ }^{9}$

The Inka views of homosexuality and 'third-gender' have been better analysed, however, ${ }^{10}$ as Inka society existed when the Spanish arrived whereas the Moche had been long gone. Dominican friar Domingo de Santo Tomas wrote carefully about same-sex temple sodomy and transvested temple attendants due to his European view of homosexuality, and described each important Inka temple as "[having] a man or two, or more, depending on the idol, who go dressed in women's attire [and]... imitate women. ...they have carnal, foul intercourse, especially with the chiefs and headmen." ${ }^{11}$ How these third-gendered individuals felt about their role is unclear, but what can be inferred is that these berdaches did participate, to some extent, in the power structure of Inka society, if for no other reason than the fact many berdaches were priests. ${ }^{12}$ Their androgyny also fits into Inka mythology as Viracocha, the Andean creator deity, has been shown in cosmological drawings to transcend gender divisions and connect the masculine to the feminine. ${ }^{13}$ This suggests that the berdache were a physical mediator between genders - a human form of this mythical discourse. The always male-sexed transgendered berdache was consequently at the very root of Andean society and mythology, and in acting as homosexual partners for Inka nobility and clergy achieved greater prominence than Spanish homosexuals ever $\operatorname{did}^{14}$

\footnotetext{
${ }^{9}$ Horswell, "Toward an Andean Theory," 34-35. Other pieces of Moche art have revealed that same-sex sodomy may have had religious significance. "Tema de la preparación" in particular depicts male figures preparing what may be a hallucinogenic substance. This substance is then poured on the genitals of two copulating figures, and may have been injected into the anus of the penetrated individual as an enema.

${ }^{10}$ Study of Inka sexuality is still rather limited though.

${ }^{11}$ Horswell, "Toward an Andean Theory," 41-42. Domingo de Santo Tomas also punished two of these transvested individuals and upon punishing them for their sin, they told Tomas "it was not their fault because from childhood they had been put there by the caciques to serve them in this cursed and abominable vice, and to act as priests and guard the temples of their idols." This was seen as an act by the devil to corrupt the Inka into thinking such nefarious acts were in fact holy.

12 See Trexler, "Gender Subordination," 78. Apart from carrying out priestly duties, berdaches were all 'sacrificially raped' during temple services. In these cases, the berdaches act as sacrifices to deities, and as seen in the sexual sacrifice accorded to the Peruvian god Pachacama, berdaches bent over at prayed and "[presented] their hindquarters for anal penetration to the god, that is, to his priests."

${ }_{13}^{13}$ Horswell, "Toward an Andean Theory," 54-55.

${ }^{14}$ See Trexler, "Gender Subordination," 73. Inka Huascar also practiced a similar action to the previously mentioned leader in the Valley of Mexico in that he forced his general to dress as a woman after losing a battle. This suggests that forced transvestism was an ever-present threat and quite humiliating, but it was temporary unlike the transvestism of the berdaches. Additionally, even though the berdaches did fill particular
} 
To better understand the Spanish perspective on homosexuality, we needn't turn any further than Tommaso d'Aquino, a thirteenth century Doctor of the Church. Thomas Aquinas (as he is better known) defined sodomy as "a violation of natural, canon, civil, and scriptural laws," and this medieval line of thought perpetuated well into the colonial period, becoming the key official teaching on homosexuality in Latin America until the eighteenth century. ${ }^{15}$ Thus, it becomes more understandable why, when the Spanish met and fought the Mexica of Tenochtitlan and witnessed extensive sodomy being practiced in the Valley of Mexico - by youths penetrating each other in temples along with other forms of institutionalised anal penetration ${ }^{16}$ - these European conquerors were perplexed. ${ }^{17}$ Their education and religion instructed them any non-procreative coitus was against not only God, but nature as well. Sodomites in Europe were effeminate or lambasted - as supported by the Spanish view of Genoan men ${ }^{18}$ - but the Mexica were the epitome of masculinity as understood in the sixteenth century. This contradiction aided the construction of Spanish conquest ideology wherein Spaniards argued only the least civilised societies partook in

roles, these roles were absolutely not positive in all cases. They were still ritually raped and sacrificed in Inka society as in Maya and Nahua civilisations.

15 Martin Austin Nesvig, "The Complicated Terrain of Latin American Homosexuality," Hispanic American Historical Review 81, no. 3-4 (2001): 694-695.

16 It is unclear if sodomy happened during actual battles, as for many Nahua groups, sodomy was practiced especially against defeated foes to portray dominance. Additionally, some scholars argue that homosexual activity was actively repressed quite heavily among the Mexica, whereas others say the opposite is true. Bernardino de Sahagun's Florentine Codex used Nahua informants to detail an ethnography of native Nahua people, and suggests that homosexuality played a role in relation to gods, religion, mockery, and sacrifice. For an analysis of Nahua belief regarding passive sodomitical partners causing misfortune, see Cecilia F. Klein, "None of the Above: Gender Ambiguity in Nahua Ideology," in Gender in Pre-Hispanic America: A Symposium at Dumbarton Oaks, ed. Cecilia F. Klein (Washington, DC: Dumbarton Oaks Research Library and Collection, 2001), 192. For discussion of forced transvestism among the Nahua as well as discussion about a lack of laws or rules regarding sodomy prior to the arrival of the Spanish, see Trexler, "Gender Subordination." For an argument that there was no suppression of homosexual activity among the Nahua prior to the arrival of the Spanish, see Geoffrey Kimball, "Aztec Homosexuality: The Textual Evidence," Journal of Homosexuality 26, no. 1 (1993): 20. For an argument that the Mexica did engage in repression of homosexual activity, see Clark L. Taylor, "Legends, Syncretism, and Continuing Echoes of Homosexuality from Pre-Columbian and Colonial Mexico," in Latin American Male Homosexualities, ed. Stephen O. Murray (Albuquerque: University of New Mexico Press, 1995), 86-87.

${ }^{17}$ Pete Sigal, "The Cuiloni, the Patlache, and the Abominable Sin: Homosexuality in Early Colonial Nahua Society," Hispanic American Historical Review 85, no. 4 (2005): 560.

${ }_{18}$ Ward Stavig, "Political "Abomination" and Private Reservation: The Nefarious Sin, Homosexuality, and Cultural Values in Colonial Peru," ed. Pete Sigal (Chicago: University of Chicago Press, 2003), 143. Spaniards deprecated the Genoese by referring to them as sodomites. For example, the Spanish poet Quevedo wrote "[A]nd we order that those [women] who have a Genoese for a lover may have a Spaniard as another, without jealousy of the first, because each of them works in a different area." This refers to heterosexual sodomy, but those who participated in anal intercourse were often understood to partake in homosexual acts as well. 
extensive sodomy, and civilisation would undo this horror. ${ }^{19}$ So began an extensive quest to dignify these savages, and beat the sin out of them. ${ }^{20}$

Vasco Núñez de Balboa claiming the Pacific Ocean for the Spanish crown in 1513 manifested Spanish attitudes toward homosexuality and sodomy in the New World. Travelling across the Panamanian Isthmus, Balboa's forces came across several berdaches, and in the first act of Spanish punishment of sodomy in the Americas, "threw some forty of these transvestites... to the dogs."21 Sexual conduct in the colonies was expected to reflect Iberian Christian norms from this point onward, and when these messages were shared with Indios, "they spit upon those they suspected to be guilty of this vice. They begged [Balboa] to exterminate them... they gave it to be understood that God held this sin in horror."22 This attitude was not shown by all naturales, but over time the majority of indigenous peoples came to stand by the Church's teachings, including those regarding same-sex sexuality. The story of Viracocha as an androgynous creator gave way to the antihomosexual fables of Sodom and Gomorrah.

It is important to note however that many of the lessons provided by the Church regarding these transgressions against God focused primarily on when this behaviour became public. Of course, to sin was still to sin regardless of where it was done, but the wrath of God was described as being especially devastating when non-heterosexual behaviours became public, or accepted. ${ }^{23}$ In the eyes of Spaniards like Fray Pedro de León ${ }^{24}$, sodomites were like butterflies:

\footnotetext{
${ }^{19}$ Sigal, "Gendered Power," 122-123.

${ }^{20}$ Individuals such as Bartolome de Las Casas contrarily attempted to rationalise the sodomy practiced by the Mexica. Las Casas noted that Mexica youth committed sodomy with one another, not older men, leading Las Casas to view the Mexica as similar to 'the ancients' in that those unable to perform proper (gendered) roles as men could still be of value to society in carrying out the roles of women. Pederasty was still viewed as the worst of all sins by Las Casa however, indicating his views on the matter were more complex than simple apologist thought.

${ }^{21}$ Stavig, "Political Abomination," 134. Only the passive partners were punished in this case, furthering arguments of the relation of power and sexual dominance.

22 Peter Martyr, as quoted in Stavig "Political Abomination," 135. These words may have been a result of fear that failure to abide by Spanish rule would lead to further bloodshed, or may truly have been the fabrications of the natives themselves. It is also possible that the Spanish chroniclers of the time 'read' their values into the observance of these practices.

${ }^{23}$ Stavig "Political Abomination," 136.

${ }^{24}$ Fray Pedro de León is not the same person as the conquistador Pedro Cieza de León.
} 
Each time getting closer and closer to the open fire. ${ }^{25}[\ldots]$ A butterfly flutters close to the flames and burns only a wing. The butterfly flutters yet closer and burns another little piece of its wing until eventually it is fully burned. [Sodomites] who did not amend themselves, driven by the sin, just like butterflies eventually will end up in the fire and burn. ${ }^{26}$

This analogy is but one of many cases in the Spanish Empire of sodomy being associated with effeminacy, and declares a message that sodomites must reverse their behaviours quickly to avoid conviction, which in most cases would lead to the aforementioned burning.

Apart from God smiting those who acted against His wishes, there was another key component of the Spanish disdain for homosexuality - honour. Honour from a gendered perspective derived from fairly simple characteristics. For men honour came from assertiveness, authority, courage, and domination (personal and sexual) of women. Conversely, female honour was the result of shame through discretion and sexual control. ${ }^{27}$ What then of men who were passive, obedient, and dominated either by women or other men, how would feminine traits or homosexual behaviour affect the honour of a man and his family in Spanish society, especially in the colonies? What if a man was masculine, but engaged in homosexual relations? Pecado nefando was indeed contra natura, and a capital crime bringing enough infamy in its own right, but the interpretations of the public and the courts were not always parallel. ${ }^{28}$

Dr. Gaspar González, whose first Inquisitorial trial took place in 1595, and the

\footnotetext{
25 The fire in this instance refers to the 'flames' of homosexual desire.

${ }^{26}$ Federico Garza Carvajal, Butterflies Will Burn: Prosecuting Sodomites in Early Modern Spain and Mexico, (Austin: University of Texas Press, 2003), 1-2.

27 Geoffrey Spurling, "Honor, Sexuality, and the Colonial Church: The Sins of Dr. González, Cathedral Canon," in The Faces of Honor: Sex, Shame, and Violence in Colonial Latin America, (Albuquerque: University of New Mexico Press, 1998), 45. See Zeb Tortorici, "Against Nature: Sodomy and Homosexuality in Colonial Latin America," History Compass 10, no. 2 (2012): 161. For women this did not only mean remaining faithful to one man, a female could not engage in any non-procreative sexual activity at all, even if she was not married or of age to be wed. In 1621, Agustina Ruiz, a 20-year-old mestiza in the Mexican town of Santiago de Querétaro, confessed in a Carmelite convent that she had been committing polución (masturbation) daily since the age of eleven. This was shocking in its own right to the Inquisition, but worse still were her "obscene and sacrilegious fantasies" and "dishonest words" about Saint Nicolas of Tolentino, Saint Diego, Jesus Christ, and the Virgin Mary. These lewd thoughts landed Ruiz in a Mexico City convent for three years.

${ }^{28}$ Spurling, "Honor, Sexuality," 47.
} 
second in 1614, was recognised as an authoritative figure in the region of La Plata and was by all accounts honourable prior to his conviction. Despite a clean record, González was named during the legal investigation of a number of men accused of sodomy in Potosí. Dr. González was said to have had sex with Juan González, a twenty-year-old man, and though these claims were initially refuted, Juan González later testified that he had had sexual relations with Dr. González five or six times over the previous year in Copacabana. ${ }^{29}$ After the execution of Juan González, the testimony of others said to have had sex with the doctor, the dismissal of the case, and the re-investigation which began in 1608 the scandal about Dr. González grew and grew until his second trial in 1614.30

Honour comes into play when regarding Dr. González taking the active role with Juan González, but an active/passive dichotomy with his other lovers. In his relations with Diego Mexía, the doctor's wealth and power made him dominant over the poorer don Diego, with Mexía willingly taking a submissive role, and thus Dr. González is in some ways upholding the values of masculine honour in being authoritative, dominant, and arguably courageous. Mexía and González were consequently seen by the public as having a relationship akin to "that of a man and a woman," to the point where some of those testifying even gendered Mexía as female. ${ }^{31}$ Therefore, Mexía suffered the dishonour of being passive, but González was not necessarily honourable for being active if he even was. He still displayed intense intimacy and emotional attachment making him vulnerable, if not dependent and therefore passive, and many referred him as puto, a term typically reserved for passive sodomites. Even if the doctor was not feminised to the same extent Mexía was, the dichotomy between passive and active meant that honour and dishonour were not clear cut.

During his first and second trials, many refused to testify against González because of his honour, but the later relationship with Mexía undermined that honourable status. Were González of lesser prestige, he surely would have been sentenced to death as most sodomites were, but instead he remained in custody in an 'honourable jail'. As such it is

\footnotetext{
${ }^{29}$ Spurling, "Honor, Sexuality," 47-48.

${ }^{30}$ Spurling, "Honor, Sexuality," 48-52.

31 Spurling, "Honor, Sexuality," 54-55.
} 
clear that honour before accusations of sodomy could save those said to be partaking in the least honourable of acts, but a blow to ones honour would be dealt regardless. ${ }^{32}$ Additionally, the perceptions of the public - some of who saw the couple as beautifully romantic - did not necessarily align with those of the Inquisition, confirming that the public view of homosexuality was not always negative.

Discussion of the Inquisition dealing with homosexual behaviour nearly always portrays sodomy as an inevitable death sentence, but, as in the case of the doctor and don Diego, pecado nefando was not always dealt with so harshly. In colonial Peru, despite IberoInka denigration, even government officials would sometimes address non-heterosexual concerns "in an understanding, if not exactly humane, manner." 33 As with all regulations in any society, the obedience the individual portrays does not reflect their personal perspective wholly. Thus, by the eighteenth century in highland locations like rural Cuzco, naturales who publicly derided sodomitical acts occasionally exercised tolerance or ignorance of non-notorious behaviours. ${ }^{34}$ This was due in large part to the broad, hurried strokes of Catholicism painted by the church on naturales. ${ }^{35}$ With the word of the church never resulting in a one hundred percent Catholic population, some indigenous rituals remained well into the eighteenth century along with past mentalities. If nothing else, there were instances where those who followed the lessons of the church showed pity on 'abominable sinners'.

For example, in 1773 a group of supposed homosexuals living in the doctrina of

\footnotetext{
32 See Spurling, "Honor, Sexuality." The couple of Mexía and González would write to one another as "a man writes to a woman," and despite the dangers of living publicly together, the two fostered their relationship openly. González was jealous of Mexía conversing with women out of fear they might take him away from the doctor, and at dinner would speak to don Diego in "words so tender and loving that no husband to his wife could say more."

33 Stavig "Political Abomination," 136.

${ }^{34}$ Stavig "Political Abomination," 137.

${ }^{35}$ Stavig "Political Abomination," 136-138. The measures taken by the church to bring Christianity to indigenous populations was rarely as simple as giving sermons. On many occasions in Andean societies Spaniards would extirpate entire populations and destroy mummified ancestors. Those practicing sodomy were sentenced to death. In the post-conquest Andes many indigenous peoples did consider themselves Catholic, but the acts of the past led to adherence to Andean beliefs, and this blending of religious and cultural beliefs led to some naturales turning a blind eye to homosexual behaviour.
} 
Yanaoca ${ }^{36}$ were exposed to the priest of the nearby town of Checa. Yanaoca's homosexuals were seen as "scandalizing the community and the surrounding territory with [their] infamous, horrible and ruinous behavior," indicating that the villagers were not tolerant of homosexual behaviours. ${ }^{37}$ Lucas Tayro was centre stage for this "vile commerce" 38 along with his accomplice Don Ramon Moscoso, kuraka of a local ayllu. As kuraka, Moscoso argued that his treatment of Tayro was part of his duty to care for the people of the community, and only acted differently with Tayro because he was polite and "de bella propiedades" (of beautiful properties [features]). ${ }^{39}$ The case was submitted to wider church review after a doctor inspected Moscoso's anus and found it inflamed and disfigured. ${ }^{40}$ Those involved noted that the perpetrators may be burned, though in this case the church did not plan to burn Moscoso if found guilty, but rather that he would be excommunicated. Ultimately the case was dismissed for lack of conclusive evidence, and so Moscoso was absolved.

What the preceding investigation demonstrates is adherence and disregard for public morality. The villagers of Yanaoca denounced Tayro and Moscoso, and the law would typically have cracked down incredibly hard on the kuraka especially with what appears to be damning evidence. With Tayor and Moscoso engaging in behaviour not in accordance with public morality, they faced what was sure to be death by burning at the stake. The church and law however were circumspect in their judgement, and allowed the case to be dropped. Therefore, the public in this case acted in the interest of public morality, but authourity showed leniency for the kuraka, revealing the compassion that even rigorous investigators could sometimes show.

\footnotetext{
${ }^{36}$ Stavig "Political Abomination," $150 \mathrm{nn} .36$. As a doctrina, Yanaoca should have had its own priest, but the 'homosexuals' of this event were denounced to the priest of Checa, indicating that Yanaoca was likely without a priest only temporarily.

37 Biblioteca Nacional del Peru (BNP), 1773, C992, Criminal contra don Ramon Moscoso, vecino del pueblo de Yanaoca y Lucas Tayro, indio del mismo pueblo, sobre el ilicito comercio con que escandalosamente vivian, quoted in Stavig "Political Abomination," 145-146.

${ }_{38}$ Biblioteca Nacional del Peru (BNP), 1773, C992, Criminal contra don Ramon Moscoso, vecino del pueblo de Yanaoca y Lucas Tayro, indio del mismo pueblo, sobre el ilicito comercio con que escandalosamente vivian, quoted in Stavig "Political Abomination," 146.

39 Biblioteca Nacional del Peru (BNP), 1773, C992, Criminal contra don Ramon Moscoso, vecino del pueblo de Yanaoca y Lucas Tayro, indio del mismo pueblo, sobre el ilicito comercio con que escandalosamente vivian, quoted in Stavig "Political Abomination," 146. This statement is rather suspicious and is part of what led to Moscoso being seen as bisexual and possibly a hermaphrodite.

${ }^{40}$ Stavig "Political Abomination," 146.
} 
For every somewhat positive outcome of male homosexuality in New Spain and Peru, there are countless occurrences of devastating violence, humiliation, and execution against "those men who wanted and loved those of their own sex." 41 Homosexuals were of course not the only ones to be denounced in colonial society, Jews, indigenous peoples, black slaves, and women were also censured. However, homosexuals are the least discussed of these condemned groups, and the only ones to be executed for "that which was only a manifestation of their individuality." 42 Crypto-Jews rejected the state religion; blacks acted in rebellious manner against white overlords; and indigenous idolaters chose to stick with their own beliefs, but homosexual men were only being themselves. In his diary, Gregory Guijo residing in Puebla de los Angeles, Mexico wrote the following anecdotal account:

Tuesday, November 6 (1658), at eleven in the morning they took out fifteen men from the Royal Prison of this Court, fourteen in order to be burned and another one, because he was a boy, received two hundred lashes and was sold to a miner for six years, all of them for committing the sin of sodomy among themselves many years before. ${ }^{43}$

The punishment of accused homosexual men when they were not as fortunate as Moscoso or González is thus revealed to be deplorable, and yet expected in this time period, as discerned from the rather detached account.

Emotion was present in the official documentation of this execution and enslavement, but it was solely negative as the criminal magistrate, Juan Manuel de Sotomayor branded the partakers of pecado nefando as "contaminated ... this cancer ... so common and widespread ... such a mortal and nefarious ailment." 44 Much of the language used by Sotomayor and the viceroy of New Spain in their letters to each other about sodomy is similar to that used when discussing groups 'dangerous' to the empire, such as idolatrous Indios and rebellious blacks. Authorities in the colonies created a mental divide between the individual sodomite - viewed as a sexual deviant - and the sodomites as a

\footnotetext{
${ }^{41}$ Serge Gruzinski, "The Ashes of Desire: Homosexuality in Mid-Seventeenth-Century New Spain," trans. Ignacio Lopez-Calvo, in Infamous Desire, ed. Pete Sigal (Chicago: University of Chicago Press, 2003), 197.

${ }^{42}$ Gruzinski, "Ashes of Desire," 197.

${ }^{43}$ Gregory Guijo, Diario, quoted in Gruzinski, "Ashes of Desire," 198.

${ }^{44}$ Gruzinski, "Ashes of Desire," 200.
} 
group - considered to conspire against the empire in their meetings. Worse yet, many putos and berdaches met in pulquerías, meaning there was the possibility of Indios and sodomites meeting as one to advance their goals was considered an ever present danger. ${ }^{45}$

When convicted sodomites were sent to the bonfire to roast in the metaphorical flames of their own lust, they did not always express remorse. Quite the contrary, some of those burned in 1658 conveyed nostalgia, lamenting the inability to continue enjoying themselves. A sixty-three-year-old mestizo, Juan Correa evoked memories of "a far-away, joyful past," recounting "that he used to be a pretty girl and that he dressed as a woman with other men and that they enjoyed themselves committing the nefarious sin." 46 Some of the other fourteen took a more narcissistic look at their past, bragging about the number of lovers they had, or discussing how they were offended that some lovers never called them cotita even though they did refer to others as such. Some scholars have speculated that these vain attitudes are what led to some of these men paying no attention to the condemnation of the church, despite their piety. Regardless, these men and countless others died at the hands of a society which wouldn't accept them as they truly were.

A glance into the lifestyles of those with infamous desires may allow better relatability and understanding of those who gave their lives for being themselves. Juan de la Vega, also reduced to ashes, was a mulatto considered by his lovers to be as delicate and effeminate as a flower, said to "wear many hanging ribbons" of the sleeves of his bodice, sitting "like a woman on the floor on a platform and ... he would make tortillas and wash and cook." 47 Female features were therefore valued by some sodomites. These acts towards effeminacy were utilised by the transvested to imitate fashionable prostitutes as well as women generally understood to be beautiful, and in some locales were the "only culturally standardised and codified alternative" to a life of machismo heterosexuality. 48 This meant that for some who were homosexual, transvestism was effectively all could execute to display their sexual individuality.

\footnotetext{
45 Gruzinski, “Ashes of Desire,” 202.

46 Gruzinski, “Ashes of Desire,” 210-211.

${ }^{47}$ AGI, Mexico, 38, exp. 57-B, quoted in Gruzinski, “Ashes of Desire,” 206.

48 Gruzinski, “Ashes of Desire,” 206.
} 
Some male homosexuals did attempt to live a double life, masculine and 'straight' in public but desiring same-sex contact in private. Part of the basis for this way of living was the fact single men in Spanish colonial society had great need for a woman's held, be they his wife or slave. The Indio Miguel de Urbina led a heterosexual life, wife and all, but his testimony revealed that "one day that he was with his wife, after having the carnal act with her, upset because it had not been with the man with whom he communicated nefariously, he grabbed a candle and set a figure of saint Baby Jesus that he had on an altar on fire." 49 The uneasiness of Urbina's predicament therefore took the form of a sacrilegious act, conveying the difficulty of the double life for homosexual men.

Men such as these did not come across one another as a result of fate (though some certainly did), but instead met like-minded individuals through word of mouth or clandestine subcultures primarily in urban spaces like colonial Puebla and Mexico City. Homes, temazcales, ${ }^{50}$ and the aforementioned pulquerías were congregation points for homosexual men, and this subculture effectively produced its own network of information and informants for those chasing their same-sex desires. ${ }^{51}$ The extent of this sodomitical subculture is unknown however, though similar networks of sodomites did exist in colonial Brazil as well, as well as in some rural areas of New Spain and Peru. What prevented these secretive groups from being discovered by the Inquisition were the local levels of tolerance for homosexuals not affecting the social order, and so most sodomites lived in less than absolute fear until their orientation became publicised.

From around 1700 to 1870, well after independence for most of the colonies, there exists almost no scholarship on Latin American homosexuality. In Iberia, very few sodomites were executed for their crimes after the eighteenth century, and Mexican

\footnotetext{
${ }^{49}$ Gruzinski, "Ashes of Desire," 207.

${ }^{50}$ See Códice Tudela, fol. 62, quoted in Zeb Tortorici, “'Heran Todos Putos": Sodomitical Subcultures and Disordered Desire in Early Colonial Mexico," Ethnohistory 54, no. 1 (2007): 53-54. The sixteenth century Codex Tudela, produced after Christian morality permeated Nahua life, defined temazacatl (Nahuatl spelling) as a "bath of hot water where offenses to our Lord are committed, because if someone became sick, he would come to bathe in this hot place that held water inside. And it happened that many men and women would enter this bath, and there inside, with such heat, men with women, and women with men, and men with men used each other in illicit ways."

51 Tortorici, "Heran Todos Putos," 51. See Lee Penyak, "Criminal Sexuality in Central Mexico, 1750-1850" (PhD diss., University of Connecticut, 1993), 249.
} 
prosecution of sexual offenses ceased after 1700. Simultaneously, the Holy Office of the Inquisition became less concerned with sodomy, and consequently very little documentation was produced in the late colonial period. ${ }^{52}$ Official inquisitorial papers produced in the earlier colonial period discussing sodomy were difficult to find as well, but that was a consequence of pecado nefando being the sin that cannot be named. Why there was so much more documentation in the early colonial period is not wholly clear. The proximity of the colonial period to the Protestant Reformation and its aftermath means it is quite possible that the devoutly Catholic Iberian empires wished to exert their religious influence to a greater magnitude. In producing extensive records for the slightest hint of heresy, any civil disobedience could be punished without relying on undependable testimony.

An absence of records on sodomy during this period is appropriate, however, as there were not and still are no conclusions concerning the history of Latin American homosexuality. What can be inferred is that traditional ideology and theology did persist throughout the eighteenth and nineteenth centuries, as homosexuality lingered as the foulest of sins. ${ }^{53}$ How the social treatment of same-sex desire was altered is left to the imagination, but contemporary thought is universal in its knowledge that modern states in Latin America treat homosexuals better than they did previously, even before the arrival of Columbus. The sodomitical butterfly no longer lives in fear of the flames of lust, instead it dances in the heat with the understanding that the only harmful aspect of the blaze is when one attempts to extinguish it.

52 Nesvig, "Complicated Terrain," 710.

53 Nesvig, "Complicated Terrain," 713. 


\section{Glossary}

ayllu - Basic kin group in the Andean region claiming ties to a shared ancestor.

berdache - An indigenous individual, usually born male, who takes on the gendered role of a woman, including female clothing, speech, and social status.

Books of Chilam Balam - Maya historical texts written in 'Zuyua speech,' translated as 'unintelligible speech.' These texts contain many rituals which would grant one with knowledge of society power over society.

contra natura - Literally against nature, used by the Spanish to describe any actions, especially sexual acts, which were considered abnormal, including anal sex, homosexual relations, oral sex, and bestiality.

cotita - Literally pansy, a nickname given to some effeminate sodomites.

doctrina - An indigenous parish.

indio - A term used by the Spanish to refer to the indigenous peoples of the Americas. tinku - An Andean practice that affirmed social relations through bringing opposites into harmony.

kuraka - The Andean equivalent of a cacique (chief).

mestizo - Offspring of Spanish and indigenous parents.

mulatto - Offspring of black and white parents.

naturale - A term used in the colonial period for indigenous peoples.

pecado nefando - Literally nefarious sin, generally used interchangeably with sodomy. pulquería - Pulque bars, wherein patrons would drink alcoholic beverages made from agave. 
puto - The Spanish equivalent of queer, used to refer to a man who is perceived as effeminate, and thought to take the passive role in anal sex.

temazcale - A swear lodge originating with indigenous Mesoamerican peoples. Typically, a permanent structure used as part of curative ceremonies, improving health, and giving birth. 


\section{Works Cited}

Carvajal, Federico Garza. Butterflies Will Burn: Prosecuting Sodomites in Early Modern Spain and Mexico. Austin: University of Texas Press, 2003.

Gruzinski, Serge. "The Ashes of Desire: Homosexuality in Mid-Seventeenth-Century New Spain.” Translated by Ignacio Lopez-Calvo. In Infamous Desire, edited by Pete Sigal, 198-214. Chicago: University of Chicago Press, 2003.

Horswell, Michael J. “Toward an Andean Theory of Ritual Same-Sex Sexuality and Third Gender Subjectivity." In Infamous Desire, edited by Pete Sigal, 25-69. Chicago: University of Chicago Press, 2003.

Kimball, Geoffrey. “Aztec Homosexuality: The Textual Evidence.” Journal of Homosexuality 26, no. 1 (1993): 7-24.

Klein, Cecilia F. "None of the Above: Gender Ambiguity in Nahua Ideology.” In Gender in PreHispanic America: A Symposium at Dumbarton Oaks, edited by Cecilia F. Klein, 183253. Washington, DC: Dumbarton Oaks Research Library and Collection, 2001.

Nesvig, Martin Austin. “The Complicated Terrain of Latin American Homosexuality.” Hispanic American Historical Review 82, no. 3-4 (2001): 689-729.

Penyak, Lee. “Criminal Sexuality in Central Mexico, 1750-1850.” PhD diss., University of Connecticut, 1993.

Sigal, Pete. "Gendered Power, the Hybrid Self, and Homosexual Desire in Late Colonial Yucatan." In Infamous Desire, edited by Pete Sigal, 102-33. Chicago: University of Chicago Press, 2003.

- . . “(Homo)Sexual Desire and Masculine Power in Colonial Latin America: Notes Toward an Integrated Analysis." In Infamous Desire, edited by Pete Sigal, 1-24. Chicago: University of Chicago Press, 2003.

- . . "The Cuiloni, the Patlache, and the Abominable Sin: Homosexuality in Early Colonial 
Nahua Society." Hispanic American Historical Review 85, no. 4 (2005): 555-93.

Spurling, Geoffrey. "Honor, Sexuality, and the Colonial Church: The Sins of Dr. González, Cathedral Canon." In The Faces of Honor: Sex, Shame, and Violence in Colonial Latin America, edited by Lyman L. Johnson: 45-67. Albuquerque: University of New Mexico Press, 1998.

Stavig, Ward. "Political "Abomination" and Private Reservation: The Nefarious Sin, Homosexuality, and Cultural Values in Colonial Peru." In Infamous Desire, edited by Pete Sigal, 134-51. Chicago: University of Chicago Press, 2003.

Taylor, Clark L. "Legends, Syncretism, and Continuing Echoes of Homosexuality from PreColumbian and Colonial Mexico." In Latin American Male Homosexualities, edited by Stephen 0. Murray: 80-99. Albuquerque: University of New Mexico Press, 1995.

Tortorici, Zeb. "Against Nature: Sodomy and Homosexuality in Colonial Latin America." History Compass 10, no. 2 (2012): 161-78.

- . ."'Heran Todos Putos": Sodomitical Subcultures and Disordered Desire in Early Colonial Mexico." Ethnohistory 54, no. 1 (2007): 35-67.

Trexler, Richard C. "Gender Subordination and Political Hierarchy in Pre-Hispanic America." In Infamous Desire, edited by Pete Sigal, 70-101. Chicago: University of Chicago Press, 2003. 